\title{
Marinimicrobium locisalis sp. nov., isolated from a marine solar saltern, and emended description of the genus Marinimicrobium
}

Correspondence Jung-Hoon Yoon jhyoon@kribb.re.kr

\author{
Jung-Hoon Yoon, So-Jung Kang, Yong-Taek Jung and Tae-Kwang Oh
}

Korea Research Institute of Bioscience and Biotechnology (KRIBB), PO Box 115, Yusong, Taejon, Republic of Korea

\begin{abstract}
A Gram-negative, motile and rod-shaped bacterial strain, designated ISL-43 ${ }^{\top}$, was isolated from a marine solar saltern of the Yellow Sea, Korea, and its taxonomic position was investigated by means of a polyphasic study. Strain ISL-43 ${ }^{\top}$ grew optimally at $\mathrm{pH} 7.0-8.0$ and $30{ }^{\circ} \mathrm{C}$ and in the presence of approximately $2 \% \mathrm{NaCl}$. It contained $\mathrm{Q}-8$ as the predominant ubiquinone and $\mathrm{C}_{16: 0}$, $\mathrm{C}_{19: 0} \omega 8 c, \mathrm{C}_{16: 1} \omega 7 c$ and/or iso- $\mathrm{C}_{15: 0} 2-\mathrm{OH}$, and $\mathrm{C}_{18: 1} \omega 7 c$ as the major fatty acids. The DNA $\mathrm{G}+\mathrm{C}$ content was $58.4 \mathrm{~mol} \%$. Phylogenetic analyses based on 16S rRNA gene sequences showed that strain ISL $-43^{\top}$ fell within the genus Marinimicrobium, clustering with Marinimicrobium agarilyticum $M 18^{\top}$ with a bootstrap value of $100 \%$. Strain ISL-43 ${ }^{\top}$ exhibited 16S rRNA gene sequence similarity values of 98.1 and $95.5 \%$ to $M$. agarilyticum $\mathrm{M} 8^{\top}$ and Marinimicrobium koreense $\mathrm{M9}^{\top}$, respectively. Strain ISL $-43^{\top}$ exhibited DNA-DNA relatedness values of 17 and $10 \%$ to M. agarilyticum KCTC $12357^{\top}$ and M. koreense KCTC $12356^{\top}$, respectively. On the basis of phenotypic, phylogenetic and genetic data, strain ISL-43 ${ }^{\top}$ represents a novel species within the genus Marinimicrobium, for which the name Marinimicrobium locisalis sp. nov. is proposed. The type strain is ISL $-43^{\top}\left(=\right.$ KCTC $22484^{\top}=$ CCUG $\left.56757^{\top}\right)$.
\end{abstract}

The genus Marinimicrobium was created by Lim et al. (2006) with the description of two species, Marinimicrobium koreense and Marinimicrobium agarilyticum. Phylogenetic analyses based on 16S rRNA gene sequences showed that the genus Marinimicrobium falls within the class Gammaproteobacteria (Lim et al., 2006). In this study, we report on the taxonomic characterization of a Marinimicrobium-like bacterial strain, ISL- $43^{\mathrm{T}}$, which was isolated from a marine solar saltern in Korea.

Strain ISL- $43^{\mathrm{T}}$ was isolated by means of the standard dilution-plating technique on marine agar 2216 (MA; Difco) supplemented with $8 \%(\mathrm{w} / \mathrm{v}) \mathrm{NaCl}$ and incubated at $30{ }^{\circ} \mathrm{C} . M$. koreense KCTC $12356^{\mathrm{T}}$ and M. agarilyticum KCTC $12357^{\mathrm{T}}$, which were used as reference strains for DNA-DNA hybridization and fatty acid analysis, were obtained from the KCTC. The morphological, physiological and biochemical characteristics of strain ISL- $43^{\mathrm{T}}$ were investigated using routine cultivation on $\mathrm{MA}$ at $30{ }^{\circ} \mathrm{C}$.

Cell morphology was examined by using light microscopy (Eclipse E600; Nikon) and transmission electron microscopy. Flagellation was determined using a Philips CM-20 transmission electron microscope with cells from exponentially growing cultures: for this purpose, cells were

The GenBank/EMBL/DDBJ accession number for the 16S rRNA gene sequence of strain ISL-43 ${ }^{\top}$ is EU874388. negatively stained with $1 \%(\mathrm{w} / \mathrm{v})$ phosphotungstic acid and the grids were examined after being air-dried. Growth under anaerobic conditions was determined after incubation in a Forma anaerobic chamber on MA and on MA supplemented with potassium nitrate $(0.1 \%, \mathrm{w} / \mathrm{v})$, both of which had been prepared anaerobically in nitrogen gas. The $\mathrm{pH}$ range for growth was determined in marine broth 2216 (MB; Difco) that was adjusted to various $\mathrm{pH}$ values ( $\mathrm{pH} 4.5-9.5$, at intervals of $0.5 \mathrm{pH}$ units) by the addition of $\mathrm{HCl}$ or $\mathrm{Na}_{2} \mathrm{CO}_{3}$. Growth in the absence of $\mathrm{NaCl}$ was investigated using trypticase soy broth (Difco) prepared without $\mathrm{NaCl}$. Growth at various $\mathrm{NaCl}$ concentrations $(0.5$ and $1-20 \%, w / v$, at intervals of $1 \%$ ) was investigated in trypticase soy broth for 0.5 and $1 \%$ or $\mathrm{MB}$ for $>2 \% \mathrm{NaCl}$. Growth at various temperatures $(4,10,20,25,28,30,35$, 37,40 and $45^{\circ} \mathrm{C}$ ) was measured on MA. Catalase and oxidase activities and hydrolysis of casein, starch and Tweens 20, 40, 60 and 80 were determined as described by Cowan \& Steel (1965). Hydrolysis of hypoxanthine, tyrosine and xanthine was tested on MA using the substrate concentrations described by Cowan \& Steel (1965). Hydrolysis of aesculin, gelatin and urea and nitrate reduction were investigated as described by Lányí (1987) with the modification that artificial seawater was used for media preparation. The artificial seawater contained $\left(1^{-1}\right.$ distilled water): $23.6 \mathrm{~g} \mathrm{NaCl}, 0.64 \mathrm{~g} \mathrm{KCl}, 4.53 \mathrm{~g}$ $\mathrm{MgCl}_{2} \cdot 6 \mathrm{H}_{2} \mathrm{O}, \quad 5.94 \mathrm{~g} \quad \mathrm{MgSO}_{4} \cdot 7 \mathrm{H}_{2} \mathrm{O}$ and $1.3 \mathrm{~g}$ 
$\mathrm{CaCl}_{2} \cdot 2 \mathrm{H}_{2} \mathrm{O}$ (Bruns et al., 2001). $\mathrm{H}_{2} \mathrm{~S}$ production was tested as described by Bruns et al. (2001). Susceptibility to antibiotics was investigated on MA plates with the following antibiotic discs ( $\mu$ g unless otherwise stated): polymyxin B (100 U), streptomycin (50), penicillin G (20 U), chloramphenicol (100), ampicillin (10), cephalothin (30), gentamicin (30), novobiocin (5), tetracycline (30), kanamycin (30), lincomycin (15), oleandomycin (15), neomycin (30) and carbenicillin (100). Acid production from carbohydrates was tested as described by Leifson (1963). Utilization of various substrates for growth was determined as described by Baumann \& Baumann (1981), using supplementation with $2 \%(\mathrm{v} / \mathrm{v})$ Hutner's mineral salts solution (Cohen-Bazire et al., 1957) and $1 \%(\mathrm{v} / \mathrm{v})$ vitamin solution (Staley, 1968). Enzyme activities were determined by using the API ZYM system (bioMérieux).

Cell biomass for DNA extraction and for isoprenoid quinone analysis was obtained from cultures grown in $\mathrm{MB}$ at $30{ }^{\circ} \mathrm{C}$. Chromosomal DNA was isolated and purified according to the method described by Yoon et al. (1996), with the addition that RNase T1 was used in combination with RNase A to minimize the contamination of RNA. The $16 \mathrm{~S}$ rRNA gene sequence was amplified by PCR using two universal primers as described previously (Yoon et al., 1998). Sequencing and phylogenetic analysis were performed as described previously (Yoon et al., 2003). Isoprenoid quinones were analysed as described by Komagata \& Suzuki (1987) using reversed-phase HPLC and a YMC-Pack ODS-A $(250 \times 4.6 \mathrm{~mm})$ column (YMC). For cellular fatty acid analysis, cell mass was harvested from MA plates after cultivation for 5 days at 30 and $35^{\circ} \mathrm{C}$, for strain ISL- $43^{\mathrm{T}}$ and from MA plates after cultivation for 5 days at $35{ }^{\circ} \mathrm{C}$ for $M$. koreense KCTC $12356^{\mathrm{T}}$ and $M$. agarilyticum KCTC $12357^{\mathrm{T}}$. The fatty acids were extracted and the fatty acid methyl esters were prepared according to the standard protocol of the Microbial Identification System (Sasser, 1990). The DNA G +C content was determined by using the method of Tamaoka \& Komagata (1984) with the modification that DNA was hydrolysed using nuclease P1 (Sigma) and the resultant nucleotides were analysed by reversed-phase HPLC. DNADNA hybridization was performed fluorometrically by the method of Ezaki et al. (1989) using photobiotin-labelled DNA probes and micro-dilution wells. Five replicate hybridizations were conducted for each sample. The highest and lowest values from each sample were excluded and the remaining three were used to calculate mean DNA-DNA relatedness values.

Morphological, cultural, physiological and biochemical characteristics of strain ISL- $43^{\mathrm{T}}$ are given in the species description and in Table 1 . The almost-complete $16 \mathrm{~S}$ rRNA gene sequence of strain ISL- $43^{\mathrm{T}}$ comprised 1486 nucleotides. In the phylogenetic tree based on the neighbourjoining algorithm, strain ISL- $43^{\mathrm{T}}$ clustered with $M$. agarilyticum $\mathrm{M}_{1} 8^{\mathrm{T}}$ and M. koreense $\mathrm{M}^{\mathrm{T}}$ (Fig. 1). The same topology was also observed in the trees constructed using the maximum-likelihood and maximum-parsimony
Table 1. Differential phenotypic characteristics of Marinimicrobium species

Strains: 1, ISL-43 ${ }^{\mathrm{T}}$ (Marinimicrobium locisalis sp. nov.); 2, M. koreense $\mathrm{M} 9^{\mathrm{T}}$ (data from Lim et al., 2006); 3, M. agarilyticum $\mathrm{M} 18^{\mathrm{T}}$ (Lim et al., 2006). All species are motile by means of a single flagellum and positive for hydrolysis of aesculin, starch and Tween 20, acid production from $\mathrm{L}$-arabinose, $\mathrm{D}$-glucose, lactose, maltose, $\mathrm{D}$-mannose and melibiose, and activities of alkaline phosphatase, esterase (C4) and esterase lipase (C8). All strains are negative for nitrate reduction, hydrolysis of gelatin, tyrosine and xanthine, acid production from inositol and mannitol, and activities of lipase (C14), cystine arylamidase, trypsin, $\alpha$-chymotrypsin, acid phosphatase, $\beta$-glucuronidase, $\beta$-glucosidase, $\alpha$-mannosidase and $\alpha$-fucosidase. + , Positive; $\mathrm{W}$, weakly positive; - , negative.

\begin{tabular}{|c|c|c|c|}
\hline Characteristic & 1 & 2 & 3 \\
\hline Cell morphology & $\begin{array}{l}\text { Short rods } \\
\text { or rods }\end{array}$ & $\begin{array}{r}\text { Short } \\
\text { rods }\end{array}$ & $\begin{array}{r}\text { Short } \\
\text { rods }\end{array}$ \\
\hline Colony colour on MA & Yellow-green & Cream & Cream \\
\hline Catalase & + & - & - \\
\hline Oxidase & + & - & + \\
\hline \multicolumn{4}{|l|}{ Hydrolysis of: } \\
\hline Agar & - & - & + \\
\hline Casein & + & - & - \\
\hline Tween 80 & - & - & + \\
\hline \multicolumn{4}{|l|}{ Acid production from: } \\
\hline D-Fructose & - & + & + \\
\hline Raffinose & - & - & + \\
\hline D-Ribose & - & + & + \\
\hline Sucrose & - & + & + \\
\hline Trehalose & - & + & + \\
\hline D-Xylose & - & + & + \\
\hline \multicolumn{4}{|l|}{ Enzyme activity (API ZYM) } \\
\hline Leucine arylamidase & $\mathrm{W}$ & + & + \\
\hline Valine arylamidase & - & + & + \\
\hline $\begin{array}{l}\text { Naphthol-AS-BI-phospho- } \\
\text { hydrolase }\end{array}$ & - & + & + \\
\hline$\alpha$-Galactosidase & - & + & - \\
\hline$\beta$-Galactosidase & - & - & + \\
\hline$\alpha$-Glucosidase & + & + & - \\
\hline$N$-Acetyl- $\beta$-glucosaminidase & - & + & + \\
\hline DNA G $+\mathrm{C}$ content $(\mathrm{mol} \%)$ & 58.4 & 57 & 58 \\
\hline
\end{tabular}

algorithms (Fig. 1). Strain ISL-43 ${ }^{\mathrm{T}}$ exhibited 16S rRNA gene sequence similarity values of 98.1 and $95.5 \%$ to $M$. agarilyticum $\mathrm{M} 18^{\mathrm{T}}$ and $M$. koreense $\mathrm{M} 9^{\mathrm{T}}$, respectively, and less than $92.3 \%$ to the other strains used in the phylogenetic analysis.

The predominant ubiquinone detected in strain ISL- $43^{\mathrm{T}}$ was Q-8 (peak area ratio of approximately $91 \%$ ). The cellular fatty acid profiles of strain ISL $-43^{\mathrm{T}}$ and the type strains of the two other Marinimicrobium species are shown in Table 2. Strain ISL- $43^{\mathrm{T}}$ had large amounts of straight-chain, cyclo, unsaturated and hydroxy fatty acids: the major components ( $>10 \%$ of total fatty acids) were $\mathrm{C}_{16: 0}, \mathrm{C}_{19: 0} \omega 8 c, \mathrm{C}_{16: 1} \omega 7 c$ and/or iso- $\mathrm{C}_{15: 0} 2-\mathrm{OH}$, and 


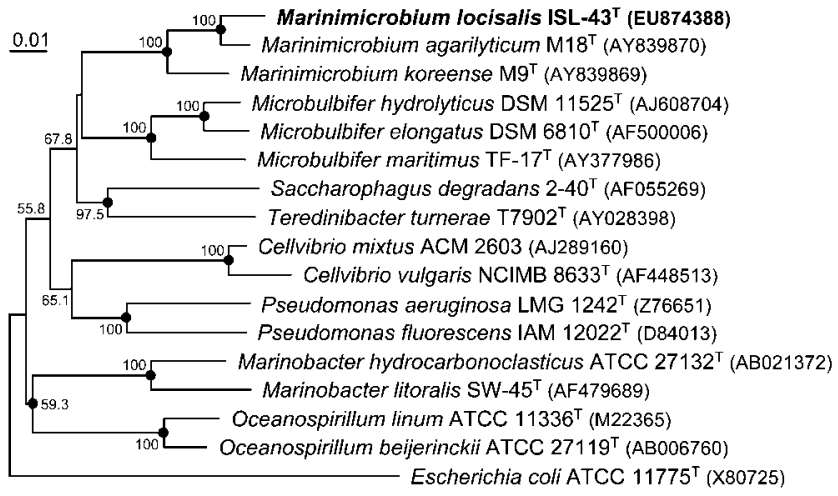

Fig. 1. Neighbour-joining phylogenetic tree based on 16S rRNA gene sequences showing the relative positions of Marinimicrobium locisalis sp. nov. ISL $-43^{\top}$, Marinimicrobium species and some other related taxa. Bootstrap values $(>50 \%)$ based on 1000 resamplings are shown at branch nodes. Filled circles indicate that the corresponding nodes were also recovered in the trees generated with the maximum-likelihood and maximum-parsimony algorithms. Escherichia coli ATCC $11775^{\top}$ was used as the outgroup. Bar, 0.01 substitutions per nucleotide position.

$\mathrm{C}_{18: 1} \omega 07 \mathrm{c}$. This is similar to those of the two recognized Marinimicrobium species, although there are differences in the proportions of some fatty acids, particularly $\mathrm{C}_{18: 1} \omega 7 c$ (Table 2). The DNA G $+\mathrm{C}$ content of strain ISL- $43^{\mathrm{T}}$ was $58.4 \mathrm{~mol} \%$. The results obtained from these chemotaxonomic analyses were consistent with the results from the phylogenetic analysis that suggest that strain ISL $-43^{\mathrm{T}}$ may belong to the genus Marinimicrobium.

Strain ISL- $43^{\mathrm{T}}$ exhibited mean DNA-DNA relatedness values of 17 and $10 \%$ to M. agarilyticum KCTC $12357^{\mathrm{T}}$ and M. koreense KCTC $12356^{\mathrm{T}}$, respectively. Strain ISL $-43^{\mathrm{T}}$ was distinguishable from recognized Marinimicrobium species through differences in several phenotypic characteristics. The phylogenetic and genetic distinctiveness and the differential phenotypic properties are sufficient to allocate strain ISL- $43^{\mathrm{T}}$ to a novel Marinimicrobium species (Wayne et al., 1987; Stackebrandt \& Goebel, 1994), for which the name Marinimicrobium locisalis sp. nov. is proposed.

\section{Description of Marinimicrobium locisalis sp. nov.}

Marinimicrobium locisalis (lo.ci.sa'lis. L. n. locus place, locality; L. gen. n. salis of salt; N.L. gen. n. locisalis from a place of salt).

Cells are Gram-negative and non-spore-forming rods, $0.2-$ $0.4 \times 0.7-3.5 \mu \mathrm{m}$. Motile by means of a single polar flagellum. Colonies on MA are circular to irregular, raised to slightly convex, glistening, smooth, yellow-green and $1.0-1.5 \mathrm{~mm}$ in diameter after incubation at $30{ }^{\circ} \mathrm{C}$ for 5 days. Growth occurs at 4 and $40{ }^{\circ} \mathrm{C}$, but not at $45{ }^{\circ} \mathrm{C}$, and at $\mathrm{pH}$ 6.0, but not at $\mathrm{pH} 5.5$ (optimum $\mathrm{pH}$ 7.0-8.0). Growth occurs in the presence of $18 \%(\mathrm{w} / \mathrm{v}) \mathrm{NaCl}$, but not
Table 2. Cellular fatty acid compositions (\%) of Marinimicrobium species

Strains: 1 , ISL- $43^{\mathrm{T}}$ (M. locisalis sp. nov.); 2, ISL-43 ${ }^{\mathrm{T}} ; 3$, M. koreense KCTC $12356^{\mathrm{T}} ; 4$, M. agarilyticum KCTC $12357^{\mathrm{T}}$. Data from this study after incubation at $30{ }^{\circ} \mathrm{C}$ (column 1) or $35{ }^{\circ} \mathrm{C}$ (columns 2-4). Fatty acids $<0.5 \%$ of the total in all strains are omitted. ECL, Equivalent chain-length; - , not detected.

\begin{tabular}{|lrrrr|}
\hline Fatty acid & $\mathbf{1}$ & $\mathbf{2}$ & $\mathbf{3}$ & $\mathbf{4}$ \\
\hline Straight-chain & & & & \\
$\mathrm{C}_{9: 0}$ & 0.1 & 0.2 & 0.7 & 0.6 \\
$\mathrm{C}_{10: 0}$ & 4.7 & 5.2 & 4.3 & 10.2 \\
$\mathrm{C}_{11: 0}$ & 0.8 & 1.0 & 1.6 & 1.9 \\
$\mathrm{C}_{12: 0}$ & 4.7 & 5.7 & 2.0 & 1.5 \\
$\mathrm{C}_{14: 0}$ & 1.8 & 2.0 & 2.5 & 1.2 \\
$\mathrm{C}_{15: 0}$ & 3.4 & 3.9 & 4.9 & 3.8 \\
$\mathrm{C}_{16: 0}$ & 20.8 & 22.0 & 21.9 & 22.9 \\
$\mathrm{C}_{17: 0}$ & 3.2 & 3.8 & 4.0 & 6.5 \\
$\mathrm{C}_{18: 0}$ & 2.2 & 2.4 & 2.0 & 2.8 \\
Unsaturated & & & & \\
$\mathrm{C}_{17: 1} \omega 8 c$ & 0.4 & 0.7 & 0.5 & 0.7 \\
$\mathrm{C}_{18: 1} \omega 7 c$ & 11.7 & 10.1 & 2.2 & 2.2 \\
Hydroxy & & & & \\
$\mathrm{C}_{10: 0} 3$-OH & 8.4 & 9.8 & 6.2 & 8.6 \\
$\mathrm{C}_{11: 0} 3-\mathrm{OH}$ & 0.4 & 0.6 & 0.7 & 0.8 \\
Cyclo & & & & \\
$\mathrm{C}_{17: 0}$ & 0.5 & 1.0 & 3.0 & 1.4 \\
$\mathrm{C}_{19: 0} \omega 8 \mathrm{c}$ & 18.7 & 17.1 & 27.7 & 17.9 \\
Summed feature 3* & 16.5 & 13.5 & 11.5 & 11.7 \\
Summed feature $7^{*}$ & - & - & 0.7 & 0.2 \\
Unknown fatty acid ECL 11.799 & 0.9 & 0.6 & 2.1 & 3.8 \\
& & & & \\
\hline
\end{tabular}

${ }^{*}$ Summed features represent groups of two or three fatty acids that could not be separated by GLC with the MIDI system. Summed feature 3 contains $\mathrm{C}_{16: 1} \omega 7 c$ and/or iso- $\mathrm{C}_{15: 0}$ 2-OH. Summed feature 7 contains $\mathrm{C}_{19: 1} \omega 6 c$, cyclo $\mathrm{C}_{19: 0} \omega 10 c$ and/or unknown fatty acid (ECL 18.846).

without $\mathrm{NaCl}$ or with more than $19 \%(\mathrm{w} / \mathrm{v}) \mathrm{NaCl}$. Optimum growth occurs in the presence of approximately $2 \%(\mathrm{w} / \mathrm{v}) \mathrm{NaCl}$. Anaerobic growth does not occur on MA or on MA supplemented with nitrate. $\mathrm{H}_{2} \mathrm{~S}$ is not produced. Tweens 40 and 60 are hydrolysed, but hypoxanthine is not. L-Arabinose, cellobiose, D-glucose, maltose, D-xylose and salicin are utilized, but D-fructose, D-galactose, D-mannose, trehalose, sucrose, acetate, citrate, succinate, benzoate, Lmalate, pyruvate, formate and L-glutamate are not. Acid is produced from cellobiose and D-galactose, but not from melezitose, L-rhamnose or D-sorbitol. Susceptible to ampicillin, carbenicillin, cephalothin, chloramphenicol, gentamicin, neomycin, polymyxin $\mathrm{B}$, oleandomycin and streptomycin, but not to kanamycin, lincomycin, novobiocin, penicillin $G$ or tetracycline. The predominant ubiquinone is Q-8. The major fatty acids ( $>10 \%$ of total fatty acids) are $\mathrm{C}_{16: 0}, \mathrm{C}_{19: 0} \omega 8 c, \mathrm{C}_{16: 1} \omega 7 c$ and/or iso- $\mathrm{C}_{15: 0}$ 2-OH, and $\mathrm{C}_{18: 1} \omega 7 c$. Other phenotypic characteristics are 
given in Table 1. The DNA G $+\mathrm{C}$ content of the type strain is $58.4 \mathrm{~mol} \%$.

The type strain, ISL- $43^{\mathrm{T}}\left(=\right.$ KCTC $22484^{\mathrm{T}}=$ CCUG $\left.56757^{\mathrm{T}}\right)$, was isolated from a marine solar saltern of the Yellow Sea, Korea.

\section{Emended description of the genus Marinimicrobium Lim et al. 2006}

The description of the genus Marinimicrobium is as given by Lim et al. (2006) with the following amendments. Cells are short rods or rods. Catalase is negative or positive.

\section{Acknowledgements}

This work was supported by the 21C Frontier Program of Microbial Genomics and Applications (grant MG05-0401-2-0) from the Ministry of Science and Technology (MOST) of the Republic of Korea.

\section{References}

Baumann, P. \& Baumann, L. (1981). The marine Gram-negative eubacteria: genera Photobacterium, Beneckea, Alteromonas, Pseudomonas, and Alcaligenes. In The Prokaryotes, pp. 1302-1331. Edited by M. P. Starr, H. Stolp, H. G. Trüper, A. Balows \& H. G. Schlegel. Berlin: Springer-Verlag.

Bruns, A., Rohde, M. \& Berthe-Corti, L. (2001). Muricauda ruestringensis gen. nov., sp. nov., a facultatively anaerobic, appendaged bacterium from German North Sea intertidal sediment. Int $J$ Syst Evol Microbiol 51, 1997-2006.

Cohen-Bazire, G., Sistrom, W. R. \& Stanier, R. Y. (1957). Kinetic studies of pigment synthesis by nonsulfur purple bacteria. J Cell Comp Physiol 49, 25-68.

Cowan, S. T. \& Steel, K. J. (1965). Manual for the Identification of Medical Bacteria. London: Cambridge University Press.

Ezaki, T., Hashimoto, Y. \& Yabuuchi, E. (1989). Fluorometric deoxyribonucleic acid-deoxyribonucleic acid hybridization in microdilution wells as an alternative to membrane filter hybridization in which radioisotopes are used to determine genetic relatedness among bacterial strains. Int J Syst Bacteriol 39, 224-229.

Komagata, K. \& Suzuki, K. (1987). Lipid and cell-wall analysis in bacterial systematics. Methods Microbiol 19, 161-207.

Lányí, B. (1987). Classical and rapid identification methods for medically important bacteria. Methods Microbiol 19, 1-67.

Leifson, E. (1963). Determination of carbohydrate metabolism of marine bacteria. J Bacteriol 85, 1183-1184.

Lim, J.-M., Jeon, C. O., Lee, J.-C., Song, S.-M., Kim, K.-Y. \& Kim, C.-J. (2006). Marinimicrobium koreense gen. nov., sp. nov. and Marinimicrobium agarilyticum sp. nov., novel moderately halotolerant bacteria isolated from tidal flat sediment in Korea. Int J Syst Evol Microbiol 56, 653-657.

Sasser, M. (1990). Identification of bacteria by gas chromatography of cellular fatty acids, Technical Note no. 1. Newark, DE: MIDI.

Stackebrandt, E. \& Goebel, B. M. (1994). Taxonomic note: a place for DNA-DNA reassociation and 16S rRNA sequence analysis in the present species definition in bacteriology. Int J Syst Bacteriol 44, 846849.

Staley, J. T. (1968). Prosthecomicrobium and Ancalomicrobium: new prosthecate freshwater bacteria. J Bacteriol 95, 1921-1942.

Tamaoka, J. \& Komagata, K. (1984). Determination of DNA base composition by reversed-phase high-performance liquid chromatography. FEMS Microbiol Lett 25, 125-128.

Wayne, L. G., Brenner, D. J., Colwell, R. R., Grimont, P. A. D., Kandler, O., Krichevsky, M. I., Moore, L. H., Moore, W. E. C., Murray, R. G. E. \& other authors (1987). International Committee on Systematic Bacteriology. Report of the ad hoc committee on reconciliation of approaches to bacterial systematics. Int $J$ Syst Bacteriol 37, 463-464.

Yoon, J.-H., Kim, H., Kim, S.-B., Kim, H.-J., Kim, W. Y., Lee, S. T., Goodfellow, M. \& Park, Y.-H. (1996). Identification of Saccharomonospora strains by the use of genomic DNA fragments and rRNA gene probes. Int J Syst Bacteriol 46, 502-505.

Yoon, J.-H., Lee, S. T. \& Park, Y.-H. (1998). Inter- and intraspecific phylogenetic analysis of the genus Nocardioides and related taxa based on 16S rRNA gene sequences. Int J Syst Bacteriol 48, 187-194.

Yoon, J.-H., Kang, K. H. \& Park, Y.-H. (2003). Psychrobacter jeotgali sp. nov., isolated from jeotgal, a traditional Korean fermented seafood. Int J Syst Evol Microbiol 53, 449-454. 